\title{
Performance analysis of gravity chemical blockers in the treatment of rising damp in masonry walls
}

\author{
R. Malaquias ${ }^{1}$, G. Bruschi ${ }^{2}$, D. Brisotto ${ }^{3 *}$ \\ *Autor de Contacto: daiane.brisotto@ufsc.br \\ ${ }^{1}$ Departamento de Engenharia Civil, Universidade Regional Integrada do Auto Uruguai e Missões, Erechim, Brasil \\ ${ }^{2}$ Departamento de Engenharia Civil, Universidade Federal do Rio Grande do Sul/UFRGS, Porto Alegre, Brasil \\ ${ }^{3}$ Departamento de Engenharia Civil, Universidade Federal de Santa Catarina/UFSC, Florianópolis, Brasil
}

\begin{abstract}
The presence of moisture in buildings is a trigger for several pathological manifestations. Among these, the rising damp, caused by the moisture of the soil, that ascends on walls due to the poor execution or lack of watertight barriers and by the characteristics of the utilized materials, constitutes one of the main causes of the degradation of the constructions, especially the oldest ones. Among the various treatment approaches, the use of chemical barriers has been shown to be more effective compared to older techniques, as well as having inferior aesthetic impact on the building and being more versatile during execution. The objective of this work is the performance analysis of the rising damp treatment in walls, through the use of chemical blockers (i.e. crystallizing and water repellant) available in the Brazilian market, with the introduction by gravity. As there are no standardized tests for such a study, experiments conducted by other researchers were used as a reference. The evaluation of the rising damp was achieved by the calculation of the water absorption rate in the specimens, allied with the images obtained by the thermographic camera. From the results, it was concluded that the treatment did not completely reduce the pathology in the walls, but both products performed well and managed to reduce the water absorption rate considerably.
\end{abstract}

Palabras clave: Rising Damp; Pathology; Chemical barrier. 


\section{RESUMO}

A presença de umidade nas edificações é desencadeante de diversas manifestações patológicas. Dentre estas, a umidade ascensional, originada pela umidade do solo que ascende pelas paredes devido à má execução ou falta de barreiras estanques e pelas próprias características dos materiais empregados, constitui uma das principais causas da degradação das construções, em especial as mais antigas. Dentre as diversas técnicas de tratamento, o uso de barreiras químicas tem demonstrado maior eficácia em relação às técnicas mais antigas, além de causar menor impacto estético à edificação e ser mais versátil durante a execução. O objetivo deste trabalho é a análise de desempenho do tratamento da umidade ascensional em paredes, através do uso de bloqueadores químicos cristalizantes e hidrofugantes disponíveis no mercado brasileiro, com a introdução dos mesmos por gravidade. A avaliação da umidade ascendente deu-se pelo cálculo da taxa de absorção de água nos corpos de prova, aliado com as imagens obtidas pela câmera termográfica. A partir dos resultados encontrados concluiu-se que o tratamento não reduziu por completo a patologia nas paredes, porém ambos os produtos obtiveram um bom desempenho, conseguindo reduzir consideravelmente as taxas de absorção de água.

Palavras chaves: Umidade ascensional; Patologia; Barreira química.

\section{RESUMEN}

La presencia de humedad en los edificios es el desencadenante de varias manifestaciones patológicas. Entre estos, la humedad ascendente, provocada por la humedad del suelo que asciende por los muros por mala ejecución o falta de barreras estancas y por las características de los materiales empleados, es una de las principales causas de la degradación de las construcciones, especialmente las más antiguas. Entre las diversas técnicas de tratamiento, se ha demostrado que el uso de barreras químicas es más eficaz que las técnicas más antiguas, además de provocar un menor impacto estético en el edificio y ser más versátil durante la ejecución. El objetivo de este trabajo es analizar el desempeño del tratamiento de la humedad ascendente en paredes, mediante el uso de bloqueadores químicos cristalizantes e hidrófugos disponibles en el mercado brasileño, con su introducción por gravedad. La evaluación de la humedad ascendente se realizó calculando la tasa de absorción de agua en las muestras, combinada con las imágenes obtenidas por la cámara termográfica. De los resultados encontrados se concluyó que el tratamiento no redujo por completo la patología en las paredes, sin embargo ambos productos obtuvieron un buen desempeño, logrando reducir considerablemente las tasas de absorción de agua.

Palabras clave: Humedad ascendente; Patología; Barreras químicas.

\section{INTRODUCCIÓN}


The presence of moisture in buildings is recurrent and can generate serious pathologies for the constructive system. Porous building materials (e.g. bricks and concrete) facilitate the transport of gases and liquids present in the environment and, in combination with other environmental factors, may lead to biological attacks, salt crystallization, chemical attacks, frost damage, etc (Sandrolini and Franzoni 2006; Bertolini, 2010). The development of these pathologies can occur due to poor execution or lack of waterproofing system, causing aesthetic impact and degradation of the structures and coatings. Furthermore, in the most serious cases, problems associated with human health (Franzoni, 2018).

As a consequence of the complexity of its treatment, one of the most challenging types of moisture manifestation is the rising damp. Worldly recognized, this phenomenon manifests itself when groundwater flows into the base of a construction and ascends through the pore structure by capillarity (Massari and Massari, 1993; Alfano, 2005; Henriques, 2007). Although it occurs with a certain frequency, it corresponds to a complex phenomenon with great behavioral unpredictability (Torres, 2014; Guimarães et al., 2016).

Many repair systems have been proposed to solve this problem. The main masonry repair techniques can be subdivided into four large groups conforming to their function (Henriques, 1994): (i) solutions to prevent the access of water from the ground; (ii) solutions to remove the excess water; (iii) solutions to stop water rising; and (iv) solutions to hide anomalies. When well adapted and executed, solutions to prevent the access of water from the ground are the most efficient repair technique in the treatment of rising damp. This solution can be performed either by reducing the absorbent section, increasing the base ventilation or through physical and chemical barriers. Although the system does not act as the origin of the phenomenon of capillary ascension, it prevents the water from reaching excessive capillary heights (Torres, 2013; Freitas et al., 2008). Currently, the implementation of chemical barriers is one of the most widely utilized methods to manage and solve the rising damp phenomena. This technique consists of creating holes in the wall along a horizontal profile, usually spaced 10 to $15 \mathrm{~cm}$, as close to the ground as possible on one or both sides of the masonry, depending mainly on the wall thickness (Dreyer and Hecht, 2001; Alfano et al., 2006; Lubelli et al., 2013). The chemical additives introduced into the holes can function by filling the pores (creating a waterproof layer in the masonry) and/or making the pores water repellent (inhibiting capillary transport). Among the pore-filler substances, also known as crystallizers or cover-pores, acrylamides, epoxy resins, alkali silicates, and inorganic silicates stand out. As for water repellent products, the most preeminent types are the organometallics, siliconates, silicones, and siloxanes. These products can have an organic solvent or be aqueous solutions or emulsions in water, being found with different viscosities (liquid, cream and gel) (Lubelli et al., 2013; Socoloski and Masuero, 2019).

One of the main problems associated with the application of chemical barriers is the difficulty of introducing the product into the pores, since they are on a large scale, filled with water. In order to present effectiveness, the chemical product must interact with all pores and voids, creating a hydrophobic or impermeable horizontal layer that prevents the access of water. If the horizontal barrier is not continuous, the water can still flow and the ascending moisture will not be interrupted. Therefore, the introduction of the product, applied with pressure/injection or gravity feed/impregnation, should be implemented aiming the layering of the treated zones (Hees et al., 2018).

The application of chemical barriers by gravity feed or impregnation (Figure 1(a)) is based on the gravity force and the materials capillarity and can be performed by inserting the chemical products without complex apparatus (Torres, 2014). In accordance with most Brazilian manufacturers, the drilling must be performed at a $45^{\circ}$ inclination and the holes should be saturated before the insertion of the products, promoting an improvement on the dispersal and consequently in the entire process (Socoloski, 2015). The application of the chemicals must be integral and continuous encompassing 
the entire treated area. The non-intrusive behavior in conjunction with the versatility of this technique results in a worldwide acknowledgment of its usage in historical buildings. However, in order to demonstrate its efficiency, some years can be required (Carrio, 1997). In the application by injection, as shown in Figure 1 (b), the fluid is pumped onto the wall by pressure, using an injection pump with special nozzles that prevent the products retraction. Several sets of mouthpieces can be attached simultaneously to the injection pump or the injection can be executed independently (Luso, 2002). The injection pressure is not necessarily constant and can vary from applicator to applicator, but it must not exceed $0.4 \mathrm{MPa}$. This range prevents the possible degradation on the constituent materials of the treated walls (Henriques, 1994).
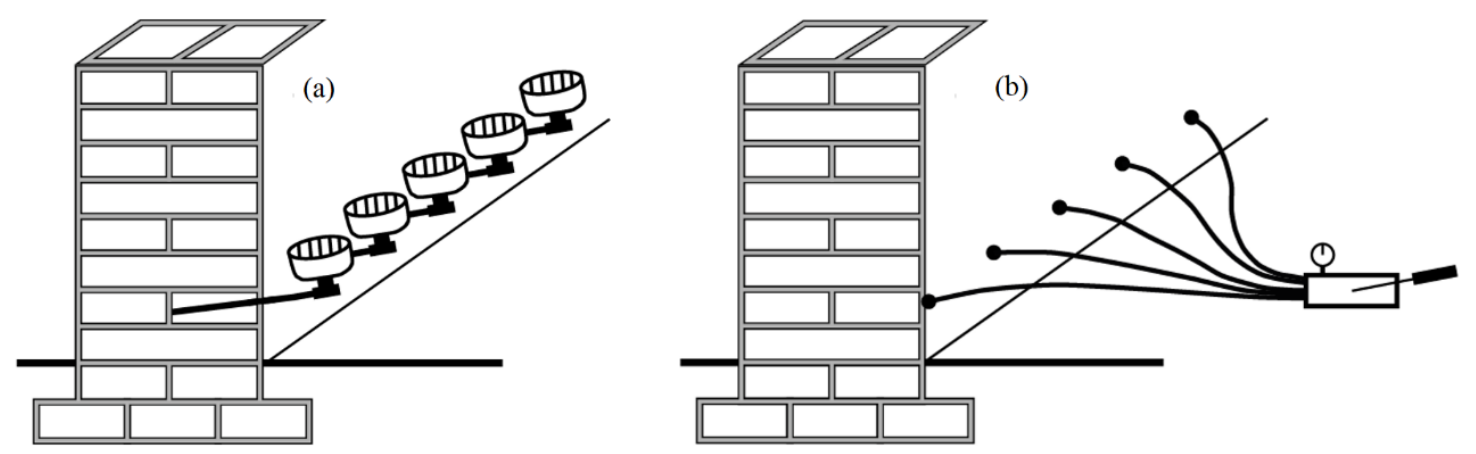

Figura 1. Introduction of chemical barriers: (a) by gravity and (b) by injection. Adapted from Henriques (1994).

The utilization of chemical barriers, either by injection or by gravity, has been widely investigated (Alfano et al., 2006; Freitas, 2014; Franzoni, 2014; Franzoni, 2018; Socoloski et al., 2019). The researches have been performed in the laboratory, on single building materials (Vanhellemon et al., 2008), assemblies of materials (Hacquebord et al., 2013) and on-site (Larsen, 2012). Although it is difficult to compare the results of different researches, considering that the experimental methods usually are not convergent, the available studies provide a valuable indication of the dispersal capacity and drying efficiency of the chemical products (Franzoni et al., 2016).The dispersal capacity should be seen as a key-factor for the creation of functional and steady chemical barriers, considering that a non-steady behavior may enable the capillary flow (Hacquebord et al., 2013). This capacity depends on the nature of the solvent and its water miscibility, as well as the chemical products viscosity. These factors are essential for the pore water displacement (I'Anson and Hoff, 1988).

Despite the existence of several methods and products to solve the rising damp problem, as discussed above, scientific research on their effectiveness, both in the laboratory and in the field, is still scarce. In addition to not being as effective as expected, the treatment solutions may aggravate the pathological manifestations if the decision-making process is inappropriate. Hence, there is substantial demand for experimental results that provide evidence on the functioning, effectiveness and limitations of these repair systems, allowing an improved comprehension of their behavior and consequently a higher success rate when applied in real masonry.

Within this context, this research aims to experimentally study the rising damp treatment on walls with the use of chemical barriers by gravity, through blocking products of distinct chemical bases. For this purpose, a crystallizing product (active silicate base) and a water repellent product (oligomeric silane-siloxanes based) were comparatively analyzed. 


\section{MATERIALS}

In this study, six small walls were constructed with the use of ceramic solid bricks and multiuse industrialized mortar. The samples were submitted to the treatment procedure of rising damp with two different chemical-based blocking products.

\subsection{Ceramic bricks}

Solid ceramic bricks of $190 \times 90 \times 50 \mathrm{~mm}$ (with tolerances up to $3 \mathrm{~mm}$ in dimensions) were adopted. Since there was no technical standard for the water absorption test in solid bricks, NBR 15270 (ABNT, 2005) was applied as a substitution. Six samples were prepared following five steps: (i) removal of loose particles and dust; (ii) drying process at $105^{\circ} \mathrm{C}$ for 24 hours; (iii) weighing for the determination of the dry mass parameter $\left(d_{m}\right)$; (iv) immersion of each sample in water during 24 hours (in room temperature).; and (v) new weighing for the determination of the wet mass parameter $\left(w_{\boldsymbol{m}}\right)$. The water absorption rate of the bricks $(W A)$ is determined according to $(1)$ and the results obtained can be visualized in Table 1 .

$$
W A(\%)=\frac{w_{m}-d_{m}}{d_{m}} \times 100
$$

Table 1. Bricks water absorption rate.

\begin{tabular}{|c|c|c|c|c|c|c|c|}
\hline & \multicolumn{6}{|c|}{ Sample } & \multirow[b]{2}{*}{$\begin{array}{c}\text { Average } \\
(\%)\end{array}$} \\
\hline & 1 & 2 & 3 & 4 & 5 & 6 & \\
\hline Dry mass (g) & 1605.48 & 1597.80 & 1587.41 & 1622.99 & 1586.27 & 1682.45 & \multirow{3}{*}{25,48} \\
\hline Wet mass (g) & 1994.56 & 2021.41 & 2017.26 & 2043.88 & 2012.05 & 2057.58 & \\
\hline WA (\%) & 24.23 & 26.51 & 27.08 & 25.93 & 26.84 & 23.30 & \\
\hline
\end{tabular}

\subsection{Industrialized mortar}

For the laying of the bricks a multiuse industrialized mortar was applied. The industrialized multiuse mortar was chosen due to the improved quality control of the product, avoiding possible variations in the results. This product is composed by Portland cement, mineral aggregates and chemical additives, with resistance to compression of $1.2 \mathrm{MPa}$ and ratio of water/dry materials of 0.2 . The mortar was prepared by mixing water until the suitable consistency and homogeneity parameters were achieved. The minimal consistency (i.e., $20 \pm 5 \mathrm{~cm}$ ) was determined following the NBR 13276 (ABNT, 2005). For the execution of the base of the walls, a mortar with $8 \mathrm{MPa}$ resistance was utilized.

\subsection{Chemical blockers}

Initially a research was carried out on the available waterproofing products for the treatment of rising damp in the Brazilian industry. Only one product of each chemical base (one crystallizing and one water repellant) was chosen for the research, due to the low availability of water repellent products for this type of treatment. The crystallizing product, named product A, was commercially available in 1-liter and 25-liter containers. The water-repellent product, named product B, was offered only in 18-liter containers. The characterization of the chemical blockers, provided by the manufacturers, is presented in Table 2. The crystallizing chemical blocker was characterized 
according to its $\mathrm{pH}$ and the rate of solids whereas the water repellant chemical blocker according to its $\mathrm{pH}$ and specific mass.

Table 2. Chemical blockers characterization.

\begin{tabular}{|c|c|c|c|c|}
\hline Product & $\mathrm{Ph}$ & $\begin{array}{c}\text { Active } \\
\text { content }\end{array}$ & Specific mass & Manufacturer info \\
\hline Crystallizing (A) & 11 & $65 \%$ & - & $\begin{array}{c}\text { Active silicate base } \\
\text { Water repellant (B) }\end{array}$ \\
6.5 to 8 & - & $1 \mathrm{~kg} / \mathrm{m}^{3}$ & Oligomeric silane siloxane base \\
\hline
\end{tabular}

\section{RESEARCH METHOD}

\subsection{Sample execution}

In order to simulate a real wall, mini walls $(50 \times 50 \times 9 \mathrm{~cm})$ were molded according to the methodology presented by Socoloski (2015), which was based on the models of Rirsch and Zhang (2010) and Freitas et al. (2008). The dimensions adopted were the largest possible considering that they had to be carried by two people, not exceeding the limit of up to $50 \mathrm{~kg}$. A total of six specimens were prepared, two for the application of the crystallizing product (PA1 and PA2), two for the water repellent product (PB1 and PB2) and two as reference (T1 and T2) without any chemical treatment.

The base of the constructed walls had approximately 50 millimeters of height, executed in a reinforced mortar, with 250 millimeters galvanized square mesh for the prevention of shear rupture. Steel bars were inserted into the mortar base, serving as hooks for the handling of the specimens, as shown in Figure 2(a). After 21 days curing process, the walls were constructed onto the bases. The specimens were composed by 2.5 bricks per row, totaling 8 rows, with vertical joints interspersed as in a real masonry, as shown in Figure 2(b).
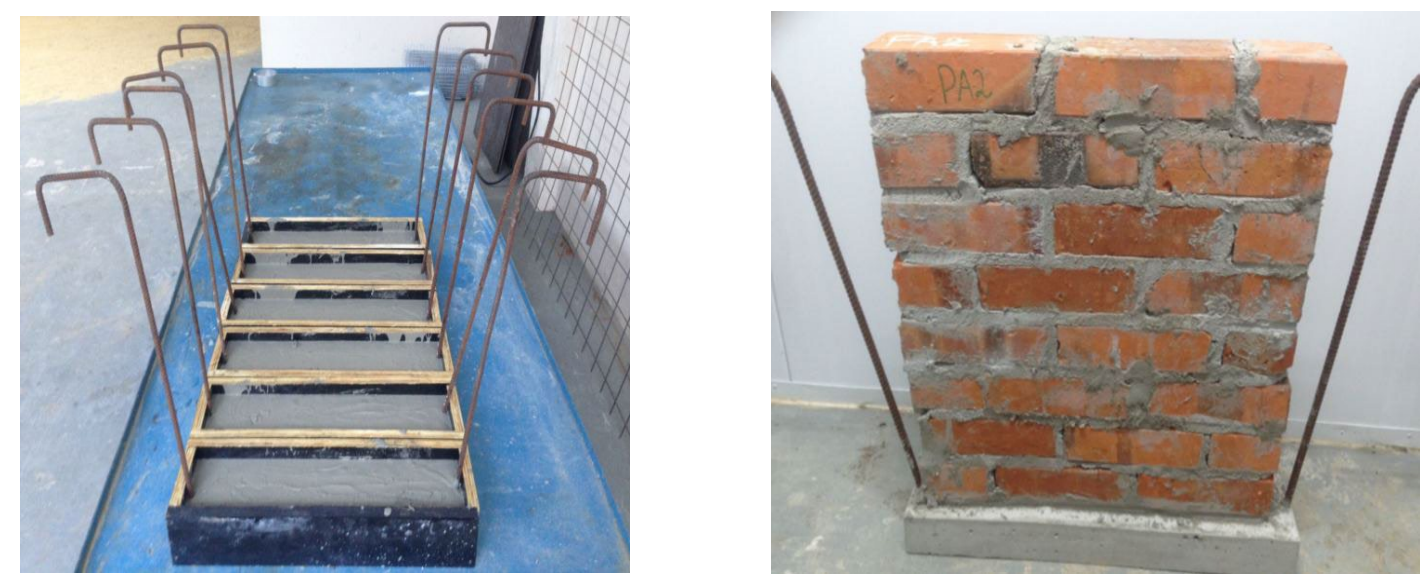

Figure 2. (a) Wall base and (b) Finished wall.

The contact of the wall with soil moisture is given through the foundation, made of cementitious materials. The use of mortar is justified on its high permeability, when compared to concrete, accelerating the process of water rising.

\subsection{Evaluation of the chemical products efficiency 3.2.1 Mass and water absorption rate}


This test provided the main parameter on the performance analysis of the treatment against rising damp. The procedures were based on the research developed by Socoloski (2015), according to the following phases:

a) Mass measurement of all specimens (dry mass before treatment), 21 days after their execution;

b) Saturation of the mortar bases (Figure 3);

c) Verification of the stabilization of the mass of the walls, which occurred between day 7 and 8 , indicating the stabilization of the water absorption. Measurement of the walls mass on day 8 (wet mass before treatment);

d) Computation of the water absorption rate before treatment, with the mass values obtained before and after the saturation of the bases;

e) Treatment of the walls with chemical blockers, inserted at $45^{\circ}$, with holes at a height of $100 \mathrm{~mm}$ and spaced by $100 \mathrm{~mm}$ each, with a total of 5 holes per wall. In order to ensure the watertightness of the scheme, the product was inserted with a system of bottles, allowing the control of the speed and volume injection (Figure 4);

f) New saturation of the bases (water layer of $50 \mathrm{~mm}$ ) for 28 days. During this period the mass was measured at 7, 14 and 28 days respectively.

g) After 28 days, the specimens were removed from the water and placed at room temperature until the stabilization of the mass, which occurred in 20 days. Mass measurement on the 20th day (dry mass after treatment);

h) The saturation process of the bases was repeated, with the treated walls, to quantify the preventive action. After 8 days a new mass measurement (wet mass after treatment) was performed to calculate the water absorption rate after treatment.

The water absorption rate was calculated with the difference between the dry and wet mass, divided by the contact area of the walls and the mortar base, in accordance with Equation 2.

$$
\text { Absorção rate }=\frac{w_{m}-d_{m}}{A}
$$

Where " $w_{m}$ " represents the wet mass of the wall, " $d_{m}$ " the dry mass of the wall and "A" the contact area of the first row of bricks with the humidity.

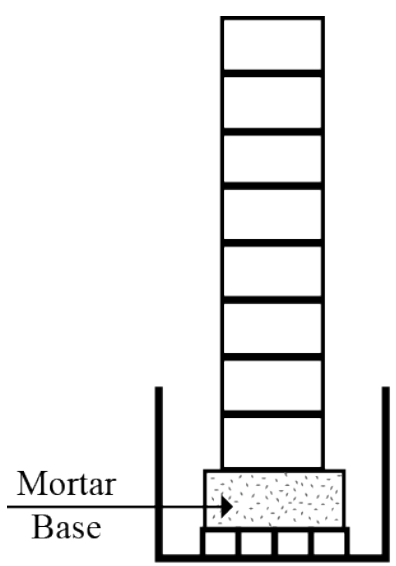

(a)

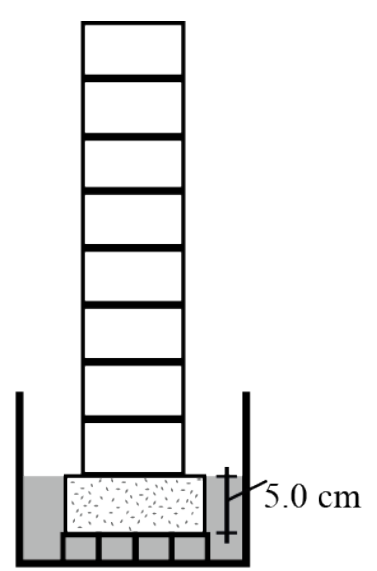

(b)

Figure 3. Specimen base saturation: (a) dry wall; (b) base in contact with water. Adapted from Socoloski (2015).

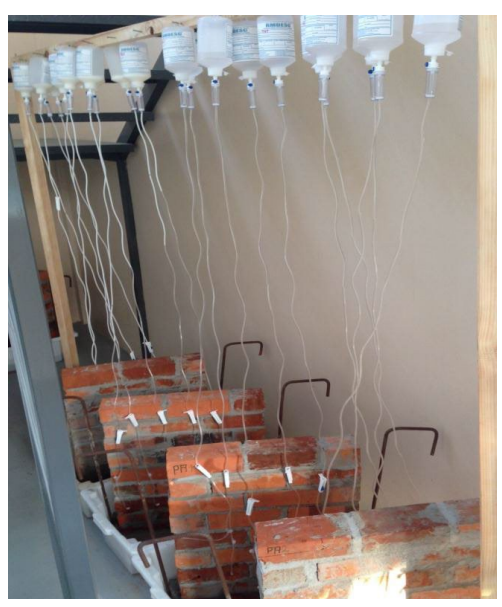

Figure 4. Application of waterproofing products 


\subsubsection{Thermography}

The thermography test, considered as qualitative or complementary, allows the mapping of a region, distinguishing areas of different temperatures. Thus, this test was utilized to monitor the moisture distribution on the specimens.

The FLIR T440 thermographic camera was utilized and, during the image capturing, some parameters of the equipment were fixed, such as the emissivity (0.81) and the distance between the specimen and the camera $(2 \mathrm{~m})$, aiming an improved resolution. The atmospheric temperature measured by the camera, at the time of the experiment, was $23{ }^{\circ} \mathrm{C}$. In addition, to improve the performance of the equipment, a dark background was assembled and installed behind the specimens, enhancing the sharpness of the images.

Using the software PSPP2018 the maximum and minimum wall temperatures were determined over the entire test period. The color scales adopted were the same for all images to allow the visual comparison. It is important to note that in this test, the camera provides only the recording of the temperature parameter, not including moisture rate or any other information. Thus, although the images contribute for a diagnosis, they are not necessarily decisive on the analysis.

\subsubsection{Cost analysis}

In order to evaluate the cost of executing this type of treatment, the value of each product was investigated, and its consumption was measured considering the thickness $(90 \mathrm{~mm})$ and length (1 $\mathrm{m})$ of the tested walls. Therefore, it was possible to estimate which of the chemical blockers presented the best cost-benefit (i.e., the lowest cost per linear meter of treated wall).

\section{RESULTS AND DISCUSSION}

\subsection{Mass measurement and water absorption rate estimation}

The mass of each tested specimen was recorded in order to calculate the absorption rate before and after the chemical treatment. The results are presented in Table 3 and Figure 5

Table 3. Mass measurement and water absorption rate before and after treatment.

\begin{tabular}{|c|c|c|c|c|c|c|c|c|c|c|}
\hline \multirow{3}{*}{ Sample } & \multirow{3}{*}{$\begin{array}{c}\text { Contact } \\
\text { area } \\
\left(\mathbf{m}^{2}\right)\end{array}$} & \multicolumn{4}{|c|}{ Before treatment } & \multicolumn{4}{|c|}{ After treatment } & \multirow{3}{*}{$\begin{array}{c}\text { Average } \\
\text { reduction } \\
(\%)\end{array}$} \\
\hline & & \multirow{2}{*}{$\begin{array}{l}\text { Dry mass - } \\
21 \text { days of } \\
\text { cure after } \\
\text { confection } \\
\quad(\mathrm{kg})\end{array}$} & \multirow{2}{*}{$\begin{array}{l}\text { Wet mass - } 8 \\
\text { days of water } \\
\text { contact with } \\
\text { the base }(\mathrm{kg})\end{array}$} & \multicolumn{2}{|c|}{$\begin{array}{l}\text { Absorption rate } \\
\qquad\left(\mathrm{kg} / \mathrm{m}^{2}\right)\end{array}$} & \multirow{2}{*}{$\begin{array}{c}\text { Dry } \\
\text { mass - } \\
21 \\
\text { days } \\
\text { drying } \\
\text { (kg) }\end{array}$} & \multirow{2}{*}{$\begin{array}{c}\text { Wet mass } \\
-8 \text { days of } \\
\text { water } \\
\text { contact } \\
\text { with the } \\
\text { base }(\mathrm{kg})\end{array}$} & \multicolumn{2}{|c|}{$\begin{array}{l}\text { Absorption rate } \\
\qquad\left(\mathrm{kg} / \mathrm{m}^{2}\right)\end{array}$} & \\
\hline & & & & $\begin{array}{c}\text { Per } \\
\text { sample }\end{array}$ & Average & & & $\begin{array}{c}\text { Per } \\
\text { sample }\end{array}$ & Average & \\
\hline T1 & 0.045 & 52.68 & 54.60 & 42.24 & \multirow{2}{*}{45.87} & 52.50 & 54.40 & 41.80 & \multirow{2}{*}{44.55} & \multirow{2}{*}{2.88} \\
\hline $\mathbf{T 2}$ & 0.045 & 51.65 & 53.90 & 49.50 & & 51.60 & 53.75 & 47.30 & & \\
\hline PA1 & 0.045 & 49.50 & 50.95 & 56.11 & \multirow{2}{*}{49.51} & 49.00 & 49.90 & 19.80 & \multirow{2}{*}{20.35} & \multirow{2}{*}{58.90} \\
\hline PA2 & 0.045 & 50.60 & 52.50 & 42.90 & & 50.55 & 51.50 & 20.90 & & \\
\hline PB1 & 0.045 & 47.90 & 50.45 & 31.90 & \multirow{2}{*}{36.85} & 47.60 & 48.25 & 14.30 & \multirow{2}{*}{11.00} & \multirow{2}{*}{70.15} \\
\hline PB2 & 0.045 & 48.50 & 50.45 & 41.80 & & 48.20 & 48.55 & $7, .0$ & & \\
\hline
\end{tabular}




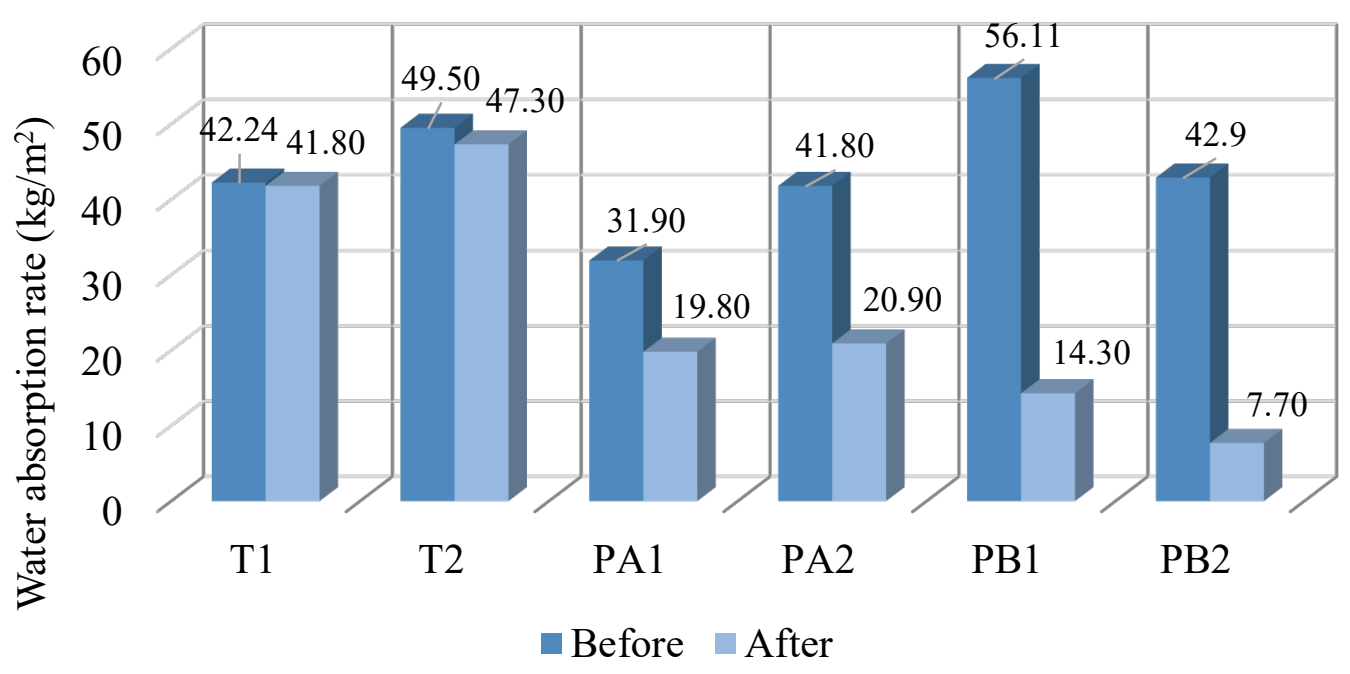

Figure 5. Mass measurement and water absorption rate before and after treatment.

The values in Table 3 demonstrate that before the beginning of treatment an increase in the specimens' mass occurred when exposed to humidity. However, according to Figure 5, the results show that both products were capable of considerably reducing the absorption rates of the treated specimens. The application of the crystallizing product resulted in an average reduction of 58.9\% in the water absorption rate, while for the water repellent product this reduction was $70.15 \%$. The fact that the control walls showed a small decrease in mass and, consequently, a decrease in the absorption rate $(2.88 \%)$, was already expected due to the equivalence process evidenced between the evaporation and absorption rate and, since this research analyzed a miniature wall, the process occurred faster than it normally would when compared to a natural size construction.

Table 4. Specimens mass during treatment.

\begin{tabular}{|c|c|c|c|}
\hline \multirow{2}{*}{ Specimen } & \multicolumn{3}{|c|}{ Mass during treatment $(\mathrm{kg})$} \\
\cline { 2 - 4 } & $\mathbf{7}$ days & $\mathbf{1 4}$ days & $\mathbf{2 8}$ days \\
\hline T1 & - & - & 54.25 \\
\hline T2 & - & - & 53.55 \\
\hline PA1 & 50.85 & 50.20 & 49.80 \\
\hline PA2 & 52.30 & 51.65 & 51.35 \\
\hline PB1 & 49.75 & 48.95 & 48.45 \\
\hline PB2 & 50.30 & 49.65 & 49.20 \\
\hline
\end{tabular}

The mass measurements during the treatment (7, 14 and 28 days after the blockers application) are shown in Table 4. The results are equivalent to the obtained by Socoloski (2015) for both types of chemical blockers, with the lowest mass values obtained at 28 days of saturation. This can be explained by the fact that, over time, the rate of evaporation exceeds the rate of absorption (this index decreases as the pores are crystallized or with water-repellent behavior due to the chemical action). In addition, the mass reduction was certainly superior with the water repellent product. These results can be visualized in Figure 6. 


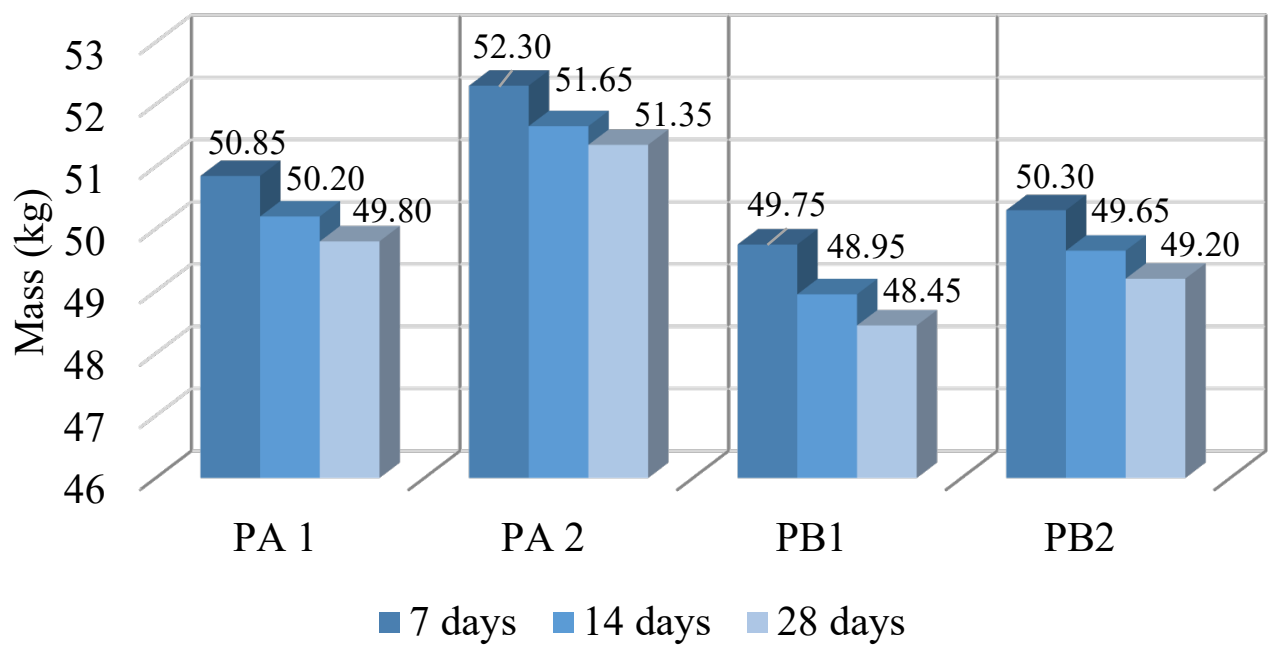

Figure 6 - Comparison between masses during treatment.

In pursuance of the performance evaluation of the products, for the prevention of the rising damp phenomenon, Figure 7 shows a comparison between wet mass before and after the treatment. Although prevention is not the main focus of the evaluated method, the results demonstrate the potential of using the products as a preventive resource in construction.

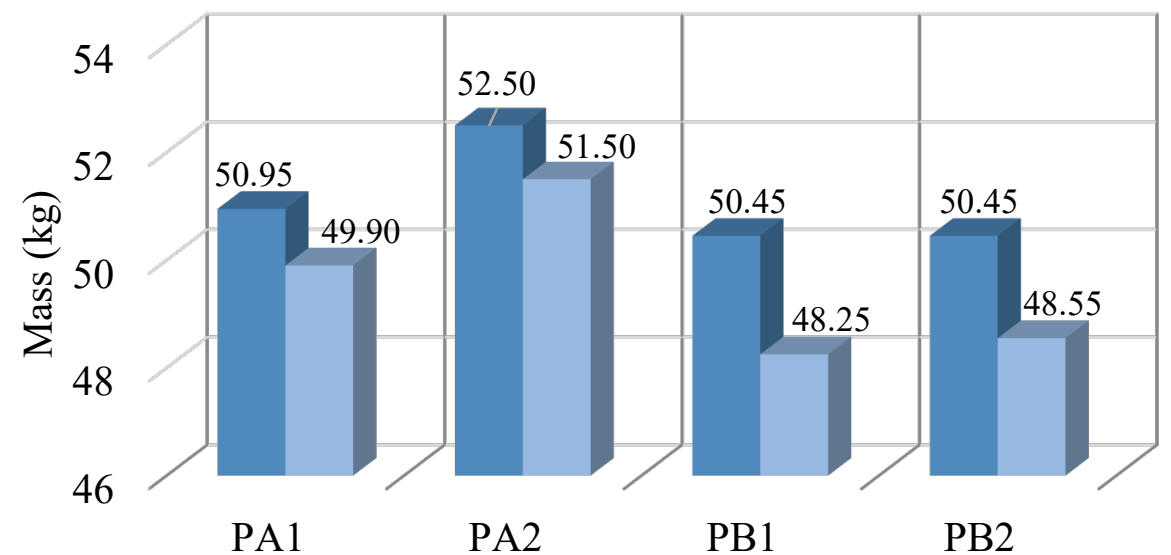

$\square$ Wet before treatment $\quad$ Wet after treatment

Figure 7 - Comparison between wet masses before and after treatment.

In order to confirm if the reductions in the absorption rate were significant, the results were statistically treated and analyzed using the variance method (ANOVA). The outcome is presented in Table 5 and classify the difference as significant.

Table 5 - ANOVA variance analysis.

\begin{tabular}{|c|c|c|c|c|c|c|}
\hline \multicolumn{2}{|c|}{} & $\begin{array}{c}\text { Square } \\
\text { sum }\end{array}$ & $\begin{array}{c}\text { Levels of } \\
\text { freedom }\end{array}$ & $\begin{array}{c}\text { Square } \\
\text { mean }\end{array}$ & $\begin{array}{c}\text { Fisher } \\
\text { test }\end{array}$ & Significant \\
\hline \multirow{3}{*}{ Absorption } & Between groups & 1199,11 & 2 & 599.55 & 47.95 & Yes \\
\cline { 2 - 7 } & Within groups & 37,51 & 3 & 12.50 & - & - \\
\cline { 2 - 7 } & Total & 1236,62 & 5 & - & - & - \\
\hline
\end{tabular}


In order to verify the dissimilarities of the groups, the post-hoc Fischer test was performed. It was observed that, statistically, there was no significant difference between the results comparing the crystallizing and water repellant products. However, when compared to untreated samples (control group), a significant reduction in the average absorption rate was obtained, indicating the efficacy of the treatment (Figure 8).

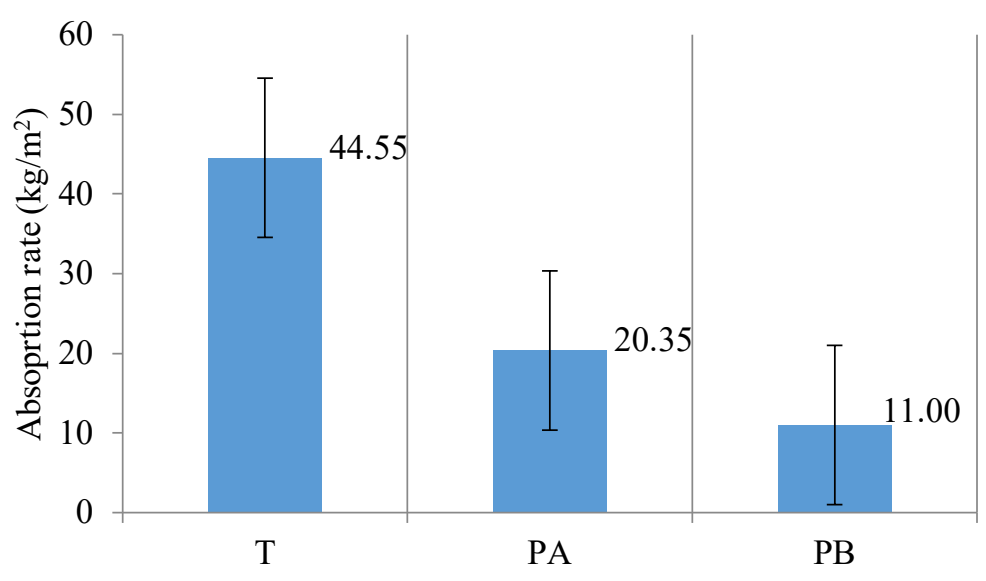

Figure 8 - Comparison between the average absorption rates after treatment

\subsection{Thermography}

The images obtained by the thermography test, Figures 9 to 12, qualitatively demonstrate the specimens temperature before the treatment (dry wall and wet wall) and at 28 days of treatment. Areas with lighter colors, orange tones, represent higher temperatures (i.e. drier regions).

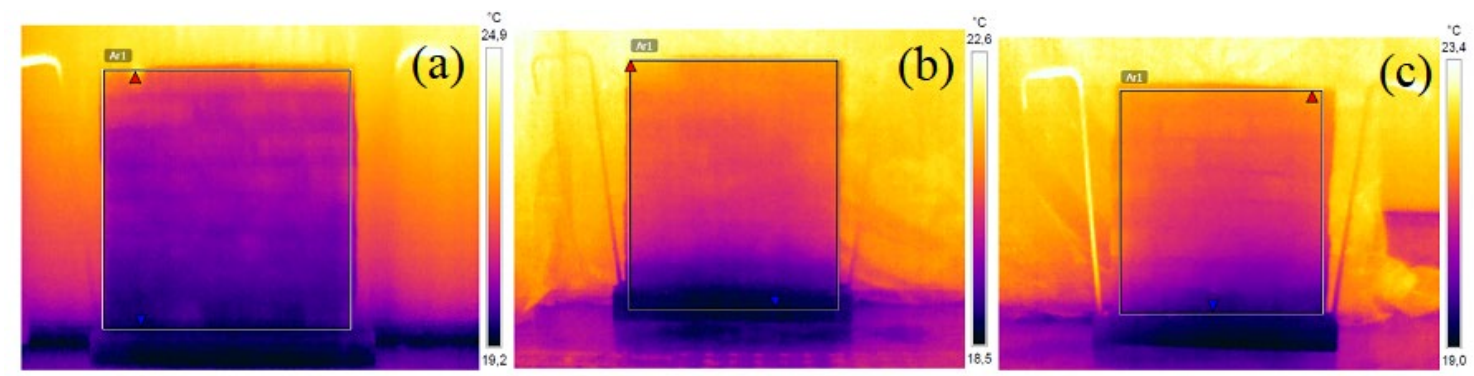

Figure 9. Sample PA1: a) dry wall; b) humid wall; and c) wall at 28 days

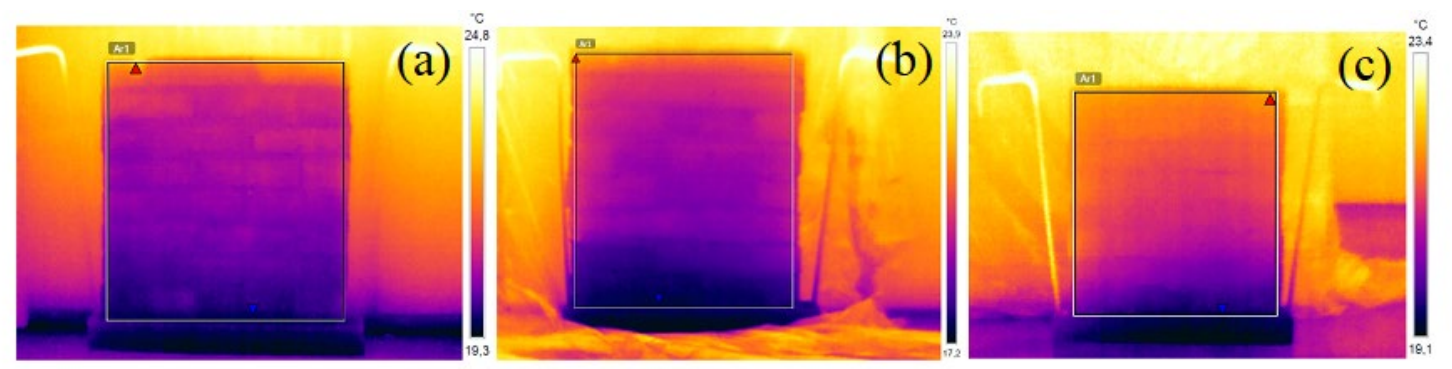

Figure 10. Sample PA2: a) dry wall; b) humid wall; and c) wall at 28 days 


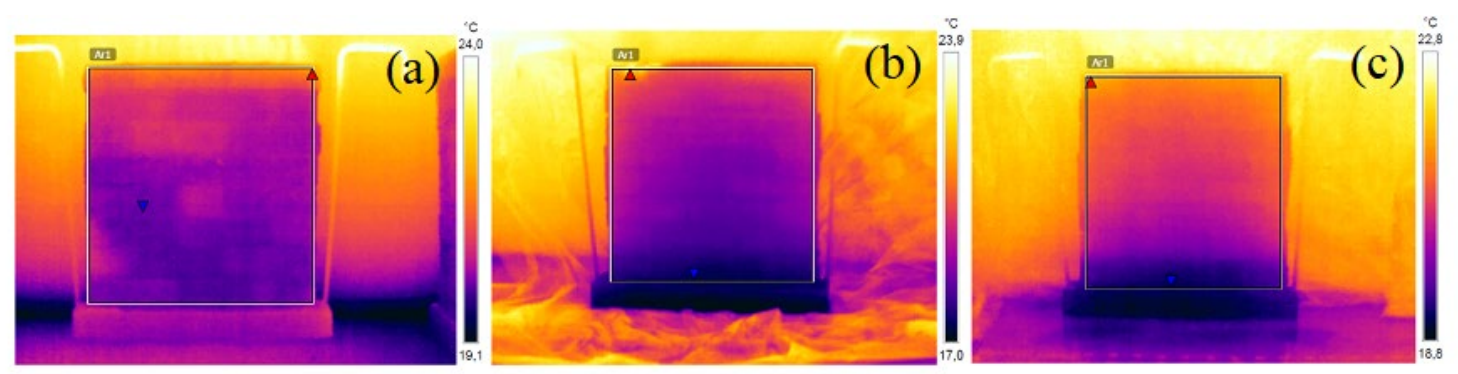

Figure 11 - Sample PB1: a) dry wall; b) humid wall; and c) wall at 28 days

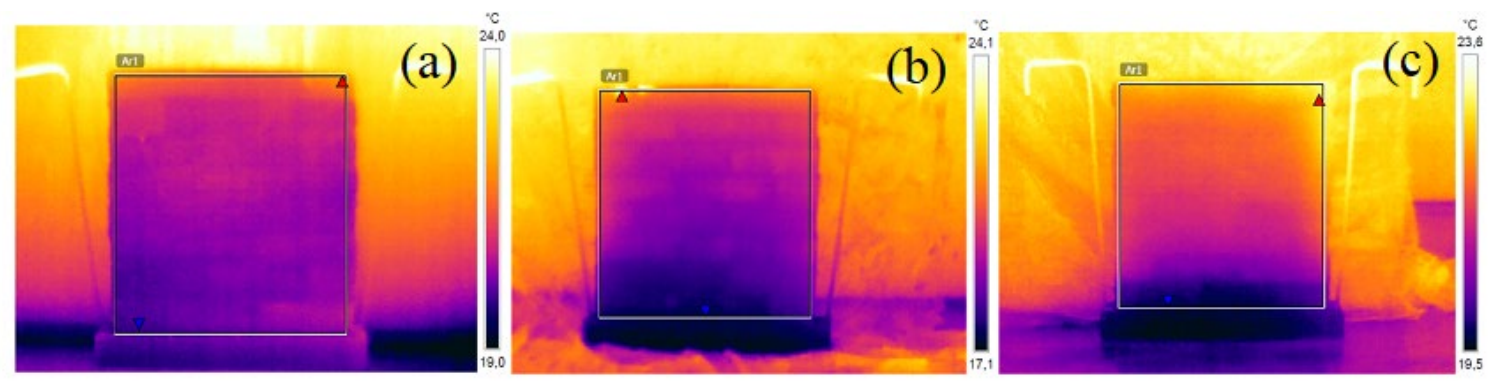

Figure 12- Sample PB2: a) dry wall; b) humid wall; and c) wall at 28 days

In general, the images initially show that, before the treatment and with the dry wall, there was moisture distributed throughout the entire wall, except in the top part and on the edges, due to the greater air contact of these locations. After the saturation of the bases, the walls show an accentuated dark blue band, near the base, which characterizes the presence of ascensional humidity. At 28 days of treatment, a reduction of the moisture range was observed, indicating a favorable outcome of the applied products.

\subsection{Cost analysis}

When analyzing the performance of the products, both were absorbed by the walls in a period of approximately 1 day, with a consumption per hole of $125 \mathrm{ml}$ for product A (crystallizing) and 60 $\mathrm{ml}$ for product $\mathrm{B}$ (water repellant). Although the reduction in the water absorption rate, caused by the two products, did not show a statistical difference, the water repellent product presented the best cost-benefit, reaching almost $1 / 5$ of the value of the crystallizing product, as shown in Table 7.

Table 7. Cost analysis

\begin{tabular}{|c|c|c|c|}
\hline \multirow{2}{*}{ Analysis Parameter } & \multicolumn{3}{|c|}{ Product } \\
\cline { 2 - 4 } & A (Crystallizing) & B (Water repellant) \\
\hline Packing volume (L) & 1.00 & 25.00 & 18.00 \\
\hline Price (R\$) & 36.50 & 595.00 & 189.00 \\
\hline Consumption (I/m) & 1.25 & 1.25 & 0.60 \\
\hline Cost (R\$/m) & 45.63 & 29.75 & 6.30 \\
\hline
\end{tabular}

The cost per linear meter of the water repellent product was $\mathrm{R} \$ 6.30$, while for the crystallizing product it reached $\mathrm{R} \$ 29.75$, representing an increase of more than 4 times. 


\section{CONCLUSIONS}

In order to experimentally investigate the performance of chemical blocking products (crystallizing and water repellent) for the treatment of the rising damp, 6 specimens were molded, and mass and thermography measurements were performed before, during and after the application of the products. It was verified that both products presented a significant reduction in the average water absorption rates of the specimens.

The crystallizing product generated an average reduction, when compared to the untreated walls, of $32 \%$ in the water absorption rate, while the water repellent product $28.18 \%$. However, statistically, this difference was not significant, indicating that both present the same performance. Regarding the cost-benefit (a decisive factor in the selection of the blocker), it was concluded that the water repellent product had an advantage over the crystallizing, with a cost about 5 times lower. Although the injection system, utilized in this research, was designed to prevent leakage and to control the application velocity, the injection was occasionally obstructed during the application of the crystallizing product, showing the necessity of studying the ideal injection speed. The execution of this technique outside the laboratory environment would probably generate ergonomics problems, due to its complexity on the equipment scope. The necessity of studies on new methods of product application is presented as indispensable on the creation of a more practical in situ system.

Finally, it should be noted that the occurrence of rising damp is not a simple pathology and the search for knowledge and new techniques, that can improve the performance of buildings and reduce treatment costs, is of great importance.

\section{REFERENCIAS}

Alfano, G., Chiancarella, C., Cirillo, E., Fato, I. F. (2006), Long-term performance of chemical damp-proof courses: twelve years of laboratory testing. Building and Environment, 41: 1060-1069.

Associação Brasileira de Normas Técnicas. (2005). NBR 13276: Argamassa para assentamento e revestimento de paredes e tetos - Preparo da mistura e determinação do índice de consistência. Rio de Janeiro.

Associação Brasileira de Normas Técnicas. (2005). NBR 15270: Componentes cerâmicos parte 3 : Blocos cerâmicos para alvenaria estrutural e de vedação - Métodos de ensaio. Rio de Janeiro.

Bertolini, L. (2010), “ Materiali da costruzione: degrado, prevenzione, diagnose, restauro”, Editore CittàStudi; $2^{\mathrm{a}}$ ed., Sondrio/Italy.

Carrió, J. M. (1997), “Patología de Cerramientos y Acabados Arquitectónicos”, Munilla-Leria; $2^{\mathrm{a}}$ ed., Madrid/Spain.

Dreyer, J.; Hecht, C. (2001), Injection methods for retrofitting of moisture damaged constructions. Transactions on the Built Environment, 55: 517-526.

Franzoni, E. (2018), State-of-the-art on methods for reducing rising damp in masonry. Journal of Cultural Heritage, 31: S3-S9.

Franzoni, E. (2014), Rising damp removal from historical masonries: a still open challenge. Construction and Building Materials, 54: 123-136. 
Franzoni, E.; Rirsch, E.; Paselli, Y. (2016). "Laboratory models for the assessment of the effectiveness of chemical damp-proofing in masonry: existing methods and some proposals for new fixtures", in: International RILEM Conference Materials, Paris.

Freitas, R. J. G. (2014), “Técnicas de tratamento/controle da humidade ascensional - Catálogo”, Masters Thesis, Faculdade de Engenharia da Universidade do Porto, Porto.

Freitas, V.P.; Torres, M.I.M.; Guimarães, A. S. (2008), “Humidade Ascensional”, FEUP edições; 1. ${ }^{\mathrm{a}}$ ed., Porto/Portugal.

Guimarães, A. S.; Delgado, M. P. Q.; De Freitas, V.P. (2016), Treatment of rising damp in historic buildings: experimental campaign of wall base ventilation and interface effect analysis. Cultural Heritage, 20: 733-738.

Hacquebord, A.; Lubelli, B.; Lubelli, R.; Nijland, T. (2013), Evaluation of spreading and effectiveness of injection products against rising damp in mortar/brick combinations. Procedia Chemistry, 8: 139-149.

Hess, R. P. J., Lubelli, B. H. A. (2018), New test methods to verify the performance of chemical injections to deal with rising damp. Journal of Cultural Heritage, 31: S52-S59.

Henriques, F. M. A. (1994), “Humidade em Paredes”. Lisboa: Laboratório Nacional de Engenharia Civil.

Henriques, F. M. A. (2007), “Humidade em Paredes". Lisboa: Laboratório Nacional de Engenharia Civil.

I'anson, S. J.; Hoff, W. D. (1988), Chemical injection remedial treatments for rising damp-I. The interaction of damp-proofing fluids with porous building materials. Building and Environment, 23: 171-178.

Larsen, P. L. (2012), Determination of water content in brick masonry walls using a dielectric probe. Journal of Architectural Conservation, 18, 47-62.

Lubelli, B.; Van Hees, R. P. J.; Hacquebord, A. (2013), Experimental study of the distribution of chemical products against rising damp in substrates with different water saturation degrees. Construction and Building Materials, 40: 891-898.

Luso, E. (2002), “Contribuição para intervenções no Centro Histórico de Bragança”. Masters Thesis, Universidade de Minho, Minho.

Massari G.; Massari I. (1993), Damp Buildings, Old and New. ICCROM, 17: 2-30.

Rirsch, E.; Zhang, Z. (2010), Rising damp in masonry walls and the importance of mortar properties. Construction and Building Materials, 24: 1815-1820.

Sandrolini, F.; Franzoni, E. (2016), An operative protocol for reliable measurements of moisture in porous materials of ancient buildings. Building and Environment, 41: 1372-1380.

Socoloski, R. F. (2015), “Tratamento de umidade ascensional em paredes através de barreiras químicas por gravidade”, Masters Thesis, Universidade Federal do Rio Grande do Sul, Porto Alegre.

Socoloski, R. F.; Masuero, A. B. (2019), Evaluation of the efficiency of the treatment for rising damp on walls through the insertion of chemical barriers by gravity. Construction and Building Materials, 210: 660-672.

Torres, I. M. (2013), Wall base ventilation system to treat rising damp: the influence of the size of the channels. Journal of Cultural Heritage, 15: 121-127. 
Torres, R. J. DE M. M. (2014), “Humidades ascensionais em paredes de alvenaria de edifícios antigos”, Masters Thesis, Instituto Superior Técnico (IST), Lisboa, 2014. 